\title{
USULAN STRATEGI PEMASARAN DALAM RANGKA MENINGKATKAN PENJUALAN DI PT. $X$
}

\author{
Yosefa \\ Program Studi Administrasi Bisnis, Universitas Katolik Parahyangan, Bandung \\ yosefa.efa@unpar.ac.id
}

\begin{abstract}
ABSTRAK
PT. X sudah berdiri selama 26 tahun dan merupakan distributor tunggal untuk 3 merek furniture yang terkenal. Hal tersebut tidak membuat PT. X dapat memasarkan produk dengan mudah. Penurunan penjualan PT. X sudah terjadi sejak tahun 2016 hingga tahun 2020. Padahal rata-rata pertumbuhan ekonomi di wilayah pemasaran PT. X cenderung stabil pada tingkat 4,66\% - 7,66\%. Penelitian ini bertujuan untuk melihat strategi pemasaran yang sudah dilakukan oleh PT. X (segmenting, targeting, positioning, marketing mix) serta menganalisis lingkungan internal dan eksternal PT. X (menggunakan analisis internal perusahaan, PESTLE Analysis, dan Porter's Five-Forces Model) untuk mendapatkan rekomendasi strategi pemasaran yang sesuai dengan kondisi PT. X agar dapat meningkatkan penjualan PT. X. Rekomendasi strategi didapatkan dari hasil analisis The Competitive Profile Matrix (CPM) yang menghasilkan 8 alternatif strategi dan The Strength-Weaknesses-Opportunities-Threats (SWOT) Matrix yang menghasilkan 22 strategi. Alternatif strategi tersebut dianalisis lebih dalam dan didapatkan 4 strategi yang diprioritas untuk diterapkan di PT. X.
\end{abstract}

Kata Kunci: Strategi Pemasaran, Marketing Mix, CPM, SWOT Matrix

\section{ABSTRACT}

PT. X has been around for 26 years and is the sole distributor for 3 well-known furniture brands. This does not make PT. X can market products easily. The decline in sales of PT. X, has occurred from 2016 to 2020 . In fact, the average economic growth in the marketing area of PT. X tends to be stable at the level of $4.66 \%-7.66 \%$. This study aims to look at the marketing strategies that have been executed by the PT. X (segmenting, targeting, positioning, marketing mix) and analyze the internal and external environment of PT. $X$ (using the company's internal analysis, PESTLE Analysis and Porter's Five-Forces Model) in order to get a recommendation marketing strategy in accordance with the condition of PT. X to increase the sales. Recommended strategies from analysis The Competitive Profile Matrix (CPM), which produces 8 alternative strategies and The Strength-Weaknesses-Opportunities-Threats (SWOT) Matrix which produces 22 strategies. These alternative strategies were analyzed more deeply and obtained 4 prioritized strategies to be implemented in PT. X.

Keywords: Marketing Strategy, Marketing Mix, CPM, SWOT Matrix

\section{PENDAHULUAN}

PT. X merupakan distributor penjual furniture yang terbuat dari plastik, aluminium, serta besi yang telah berdiri sejak tahun 1990 . Menurut Oxford (2014), furniture merupakan "large movable things, for example: tables, chairs, and the other similar things in a house or office". Di Indonesia, furniture sering dikenal dengan beberapa sebutan seperti: mebel, perabotan, perabot, dan perkakas rumah. Irawati dan Purnomo (2012) menjelaskan bahwa "mebel adalah segala bentuk perabot dan perlengkapan yang digunakan untuk memenuhi fungsi ruang di dalam sebuah rumah, baik yang terbuat dari kayu, bambu, besi, aluminium, rotan, plastik, karet, kaca, fiber, dan lain-lain”. Berdasarkan Klasifikasi Baku Lapangan Usaha Indonesia (KLBI) 2020, PT. X berada dalam kategori G (Perdagangan Besar dan Eceran; Reparasi dan Perawatan Mobil dan Sepeda Motor) dengan subgolongan 46491 (Perdagangan Besar Peralatan dan Perlengkapan Rumah Tangga).

Secara spesifik, laju pertumbuhan PDB serta distribusi PDB lapangan usaha tersebut dapat dilihat pada Gambar 1. Laju pertumbuhan Produk Domestik Bruto (PDB) untuk lapangan usaha Kategori G pada Gambar 1 memperlihatkan bahwa pertumbuhan ekonomi Indonesia di sektor Perdagangan Besar dan Eceran; Reparasi dan Perawatan Mobil dan Sepeda Motor mengalami penurunan yang sangat signifikan pada tahun 2020 . Hal tersebut menunjukkan indikasi bahwa konsumen dalam lapangan usaha Kategori G 
mengalami pelemahan dalam daya beli. Salah satu penyebab utama penurunan tersebut adalah pandemi yang melanda Indonesia. Kompas (2020) menginformasikan bahwa hampir semua sektor di Indonesia mengalami dampak akibat pandemi virus corona yang diakibatkan oleh pembatasan aktivitas masyarakat yang berdampak pada aktivitas bisnis dan perekonomian Indonesia. Kondisi tersebut juga dirasakan oleh PT. X. Jika dilihat dari Gambar 2, penurunan total penjualan pada PT.X terjadi setelah tahun 2016 hingga tahun 2020. Hal ini menunjukkan bahwa penurunan penjualan tidak hanya terjadi karena adanya pandemi di Indonesia.

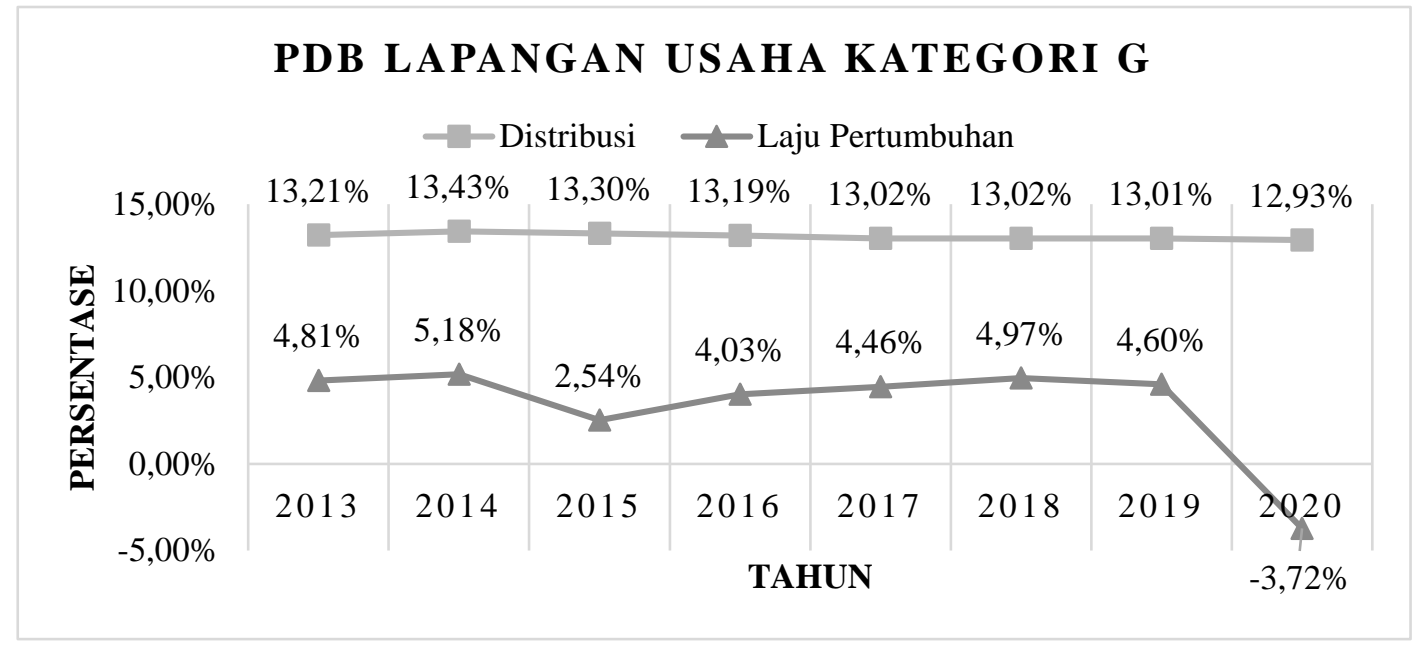

Gambar 1. PDB untuk Lapangan Usaha Kategori G Tahun 2013-2020

Sumber: Diolah dari Statistik Indonesia (Badan Pusat Statistik) Tahun 2017, 2019 dan 2021

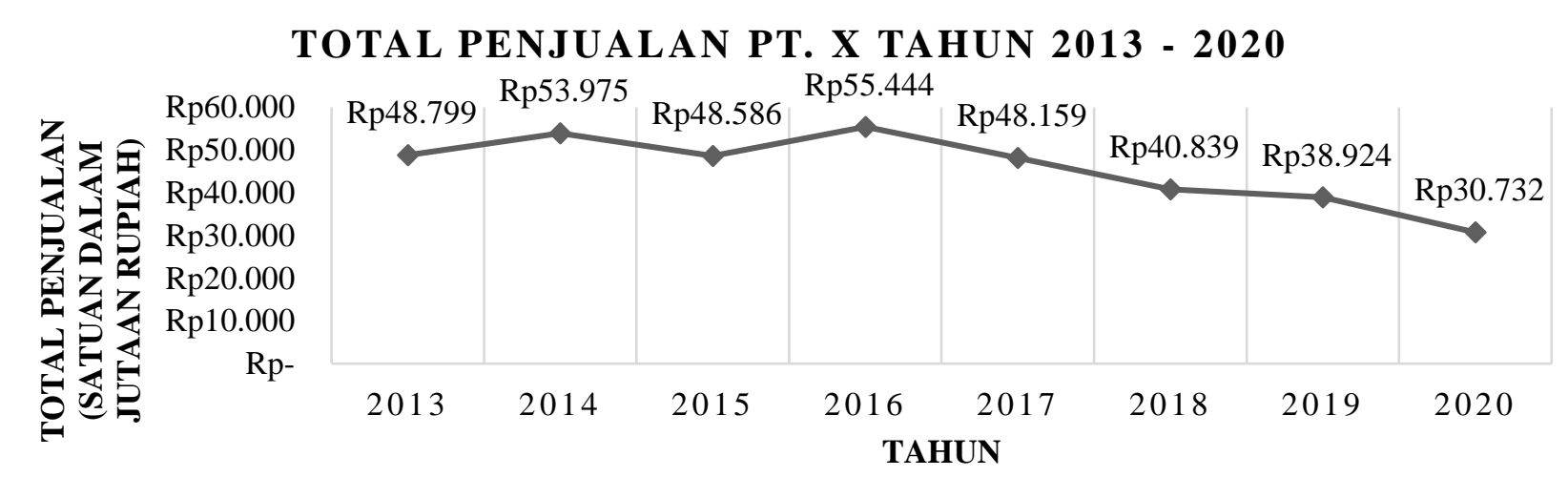

Gambar 2. Total Penjualan PT. X Tahun 2013-2020

Sumber: Diolah dari Laporan Penjualan PT. X (Satuan dalam jutaan rupiah)

PT. X merupakan perusahaan yang menjual produk ke toko-toko, dimana wilayah pemasarannya tersebar ke 14 daerah yang ada di Jawa Barat dan Jawa Tengah. Tabel 1 menunjukkan wilayah pemasaran PT. X beserta jumlah konsumen PT. X di masing-masing wilayah tersebut. Tampak bahwa ada 8 wilayah yang berkontribusi besar dalam penjualan PT. X, yaitu: Kota
Bandung, Kabupaten Bandung, Kabupaten Bandung Barat, Kota Cimahi, Kabupaten Cianjur, Kota Tasikmalaya, Kabupaten Subang, dan Kota Banjar. Untuk wilayah Jawa Tengah, PT. X baru memasarkan di Kota Tegal saja dengan jumlah konsumen sebanyak 1 toko. Hal ini dikarenakan PT. X baru mencoba melakukan penjualan di luar wilayah Jawa Barat. Pertumbuhan ekonomi pada wilayah pemasaran PT. X terlihat pada Gambar 3. 
Tabel 1. Wilayah Pemasaran dan Jumlah Konsumen PT. X

\begin{tabular}{|c|l|c|c|}
\hline No. & Wilayah Pemasaran PT. X & Konsumen PT. X (Toko) & Persentase Jumlah Konsumen PT. X \\
\hline 1 & Kota Bandung & 62 & $19.94 \%$ \\
\hline 2 & Kabupaten Bandung & 53 & $17.04 \%$ \\
\hline 3 & Kabupaten Bandung Barat & 49 & $15.76 \%$ \\
\hline 4 & Kota Cimahi & 20 & $6.43 \%$ \\
\hline 5 & Kabupaten Cianjur & 20 & $6.43 \%$ \\
\hline 6 & Kota Tasikmalaya & 16 & $5.14 \%$ \\
\hline 7 & Kabupaten Subang & 16 & $5.14 \%$ \\
\hline 8 & Kota Banjar & 15 & $4.82 \%$ \\
\hline 9 & Kabupaten Garut & 15 & $4.82 \%$ \\
\hline 10 & Kabupaten Ciamis & 12 & $3.86 \%$ \\
\hline 11 & Kabupaten Indramayu & 11 & $3.54 \%$ \\
\hline 12 & Kabupaten Kuningan & 10 & $3.54 \%$ \\
\hline 13 & Kabupaten Sumedang & 1 & $3.22 \%$ \\
\hline 14 & Kota Tegal & $\mathbf{3 1 1}$ & $0.32 \%$ \\
\hline & Total & $100 \%$ \\
\hline
\end{tabular}

Sumber: Diolah dari Data PT. X

\section{RATA-RATA PERTUMBUHAN EKONOMI KONSUMEN PT.X TAHUN 2013 - 2019}

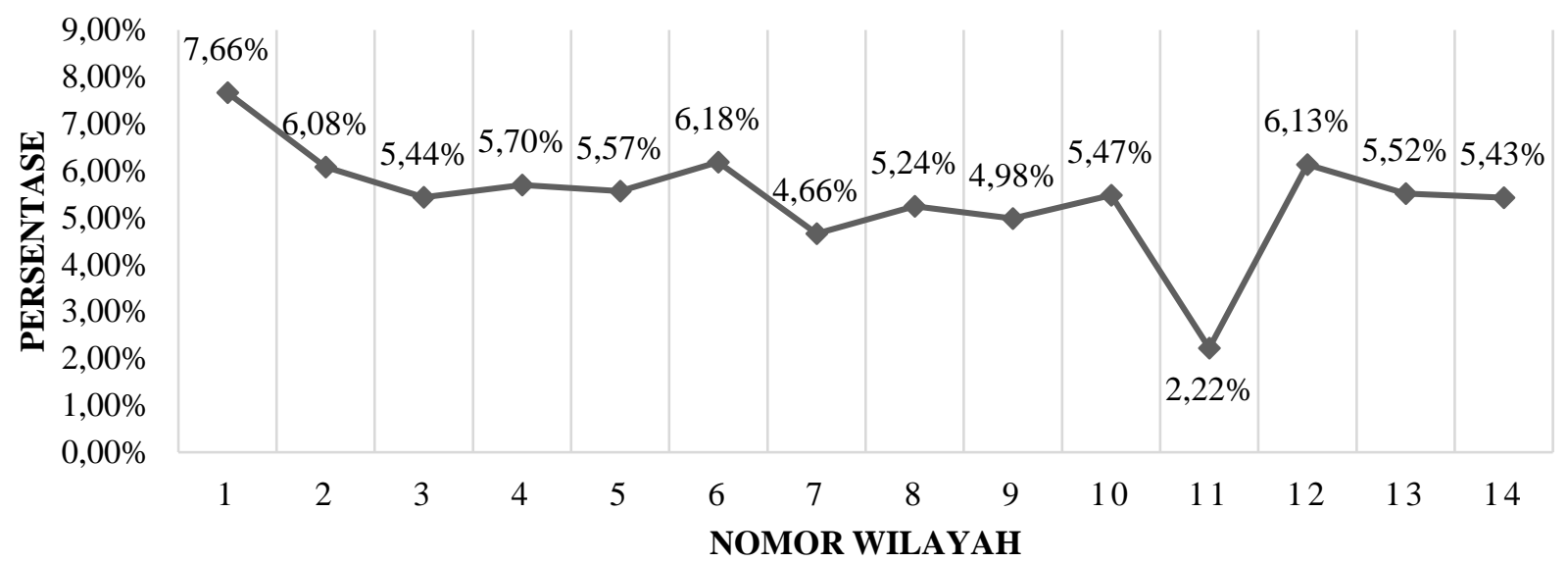

Gambar 3. Rata-rata Pertumbuhan Ekonomi Wilayah Pemasaran PT. X Tahun 2013 - 2019 Sumber: Diolah dari Data PDRB Jawa Barat dan Jawa Tengah (Badan Pusat Statistik) Tahun 2013 - 2019

Berdasarkan Gambar 3 terlihat bahwa ratarata pertumbuhan ekonomi di wilayah pemasaran PT. X cenderung stabil dengan tingkat rata-rata pertumbuhan ekonomi berkisar antara 4,66\% $7,66 \%$. Jika dilihat berdasarkan jumlah konsumen dan persentase rata-rata pertumbuhan ekonominya, PT. X sudah melakukan pilihan yang tepat dengan memiliki jumlah konsumen terbanyak di wilayah Kota Bandung, Kabupaten Bandung, dan

Kabupaten Bandung Barat. Meskipun demikian, pemasaran yang dilakukan PT. X masih belum optimal karena sebenarnya PT. X memiliki peluang untuk menambah jumlah konsumen dibeberapa wilayah yang memiliki persentase pertumbuhan ekonomi yang cukup tinggi, seperti di Kota Tasikmalaya $(6,18 \%)$ dan Kabupaten Kuningan $(6,13 \%)$. Selain itu, PT. X sebaiknya melakukan analisis lebih dalam terkait wilayah Kabupaten Indramayu karena rata-rata pertumbuhan ekonomi di wilayah tersebut sangat jauh berbeda dibanding wilayah lain.

Pemilik PT. X menyatakan bahwa meskipun PT. X sudah berdiri selama 26 tahun dan 
merupakan distributor tunggal di Bandung untuk 3 merek furniture yang terkenal dikalangan masyarakat menengah ke bawah (Club, Master, Mascot), hal tersebut tidak membuat PT. X dapat memasarkan produk dengan mudah. Saat ini pemasaran PT. X masih dilakukan secara door to door, dimana pihak PT. X menawarkan produk dari satu toko ke toko lain menggunakan katalog dari produsen untuk memudahkan konsumen dalam mengetahui bentuk dan spesifikasi produk yang ditawarkan. Promosi yang dilakukan oleh PT. X pun tidak jauh berbeda dengan pesaingnya, dimana PT. X membuat sistem paket (beli 20 unit gratis 1 unit) hanya jika promosi tersebut dilakukan oleh produsen yang bersangkutan. Pemilik PT. X mengatakan bahwa selama PT. X berdiri, tidak ada strategi pemasaran khusus yang diterapkan dalam PT. X. Tetapi, melihat situasi yang terjadi saat ini, pemilik PT. X berpendapat bahwa PT. X memerlukan strategi pemasaran yang baru untuk meningkatkan penjualan dalam kondisi daya beli masyarakat yang sedang menurun saat ini.

Berdasarkan konsisi tersebut maka penelitian berjudul "Usulan Strategi Pemasaran Dalam Rangka Meningkatkan Penjualan di PT. X” bertujuan untuk: (1) mengetahui strategi pemasaran yang dijalankan oleh PT. X saat ini, (2) menganalisis lingkungan internal dan eksternal PT. X., dan (3) menentukan rekomendasi strategi pemasaran yang sesuai bagi PT. X berdasarkan analisis lingkungan internal dan eksternal PT. X.

\section{LANDASAN TEORI}

\section{Pengertian Strategi}

Kotler (2016) menyatakan "The concept of "strategy" comes from the Greek word "strategos," meaning "leadership" in the military sense: it concerns planning the deployment of resources to achieve certain objectives". Bagi David (2015), "Strategies are the means by which long-term objectives will be achieved". Definisi lain dikemukakan oleh Wilkinson dan Kannan (2013), dimana "Strategy provides a sense of unity, direction, and purpose, as well as accommodating the changes necessitated by the firm's environment". Rao (2010) mendefinisikan strategi sebagai " a unified, comprehensive, and integrated plan that relates to the strategic advantages of the firm to the challenges of the environment." Berdasarkan definisi-definisi tersebut dapat dikatakan bahwa strategi merupakan perencanaan perusahaan dalam mencapai tujuan jangka panjang yang tidak lepas dari kondisi internal dan eksternal perusahaan.

\section{Analisis Lingkungan Internal Analisis Strategi Pemasaran}

Ferrel dan Hartline (2014) mendefinisikan strategi pemasaran sebagai "a plan for how the organization will use its strengths and capabilities to match the needs and requirements of the market". Agar dapat mengembangkan strategi pemasaran, organisasi harus memilih kombinasi yang tepat antara target market dengan marketing mix. Oleh karena itu dalam perancangan strategi pemasaran diperlukan analisis lebih dalam terkait:

a) Segmenting

Segmenting umumnya dikenal sebagai market segmentation. Menurut Ferrel dan Hartline (2014), segmenting adalah "the process of dividing the total market for a particular product or product category into relatively homogeneous segments or groups". Ada 5 kategori dalam segmenting business market, yaitu: Type of organization, Organizational characteristics, Benefits sought or buying process, Personal and psychological characteristics, dan Relationship intensity.

b) Targeting

Targeting umumnya dikenal sebagai target marketing strategies. Menurut Ferrel dan Hartline (2014), target marketing strategies dipilih berdasarkan evaluasi dari daya tarik setiap segmen dan apakah masing-masing segmen menawarkan kesempatan yang sesuai dengan capabilities dan resources perusahaan. Ada 5 strategi dasar yang digunakan organisasi dalam pemilihan target, yaitu: Single segment targeting, Selective targeting, Mass market targeting, Product specialization, dan Market specialization.

c) Positioning

Ferrel dan Hartline (2014) menyatakan bahwa positioning mengacu pada penciptaan mental 
image dari produk yang ditawarkan dan fiturfitur pembedanya dalam benak target pasar.

\section{d) Marketing Mix}

Menurut Tjiptono (2015), ada 7 elemen utama dalam Marketing Mix sebuah perusahaan jasa, yaitu:

i. Product (barang atau jasa yang secara langsung memenuhi kebutuhan dan keinginan dasar konsumen). Kotler dan Keller (2012) menyebutkan bahwa product terdiri atas: product variety, quality, design, features, brand name, packaging, sizes, services, warranties, dan returns.

ii. Price (merupakan satu-satunya elemen yang berhubungan dengan pendapatan dan laba, memiliki hubungan langsung dengan permintaan konsumen, elemen yang paling mudah diubah, secara umum merupakan indikator kualitas bagi konsumen). Kotler dan Keller (2012) menyebutkan bahwa price terdiri atas: list price, discounts, allowances, payment period, dan credit terms.

iii. Place (mendapatkan produk di tempat yang tepat, waktu yang tepat, jumlah yang tepat pada biaya terendah yang memungkinkan). Kotler dan Keller (2012) menyebutkan bahwa place terdiri atas: channels, coverage, assortments, locations, inventory, dan transport.

iv. Promotion (koordinasi seluruh aktivitas promosi untuk menghasilkan kesamaan dalam customer focused message). Kotler dan Keller (2012) menyebutkan bahwa promotion terdiri atas: sales promotion, advertising, sales forces, public relations, direct marketing.

v. People (personil/salespeople yang menyampaikan jasa merupakan elemen kunci dalam memberikan pengalaman positif dan berkesan bagi pelanggan). Menurut Kotler dan Keller (2012) ada 7 tugas yang dilakukan oleh salespeople, yaitu: prospecting, targeting, communicating, selling, servicing, information gathering, dan allocating.

vi. Physical evidence (bukti fisik beperan penting dalam meyakinkan pelanggan bahwa mereka menerima layanan berkualitas prima). Ferrel dan Hartline (2014) menyatakan bahwa physical evidence dapat dilihat sebagai bukti nyata dari layanan yang meliputi: materi tertulis, fasilitas layanan, people atau peralatan, serta lingkungan dimana layanan tersebut disampaikan.

vii. Process (perusahaan jasa wajib merancang proses penyampaian jasa yang superior, tidak birokratis, dan berorientasi pada pelanggan). Zimmerman dan Blythe (2013) menyebutkan bahwa ada beberapa hal yang harus diperhatikan dalam process, yaitu: speed of response, manufacturing process issues, application of process knowledge, changes to product, projects management issues, decision-making process knowledge, special attention in relation to deliveries, design, quotes, dan cost reduction.

\section{Analisis Internal Perusahaan}

Grant (2010) menyatakan bahwa strategi berkaitan dengan pencocokan resources dan capabilities perusahaan terhadap peluang yang muncul dalam lingkungan eksternal. Oleh karena itu penting bagi perusahaan untuk menganalisis resources, capabilities dan competitive advantage yang dimiliki.

a) Resources

Menurut Grant (2010), "resources are the productive assets owned by the firm". Tujuan utama dari resources analysis bukan untuk menghitung aset perusahaan tetapi untuk memahami potensial aset yang dapat menciptakan competitive advantage. Perusahaan terdiri atas 3 jenis resources, yaitu: Tangible resources, Intangible resources, dan Human resources.

b) Organizational Capabilities

Grant (2010) menyatakan bahwa "capabilities are what the firm can do". Ada 2 jenis pendekatan yang digunakan untuk mengklasifikasikan organizational capabilities, yaitu: functional analysis dan value-chain analysis. Hanya functional analysis yang dibahas dalam penelitian ini. Functional analysis mengidentifikasi organizational capabilities dalam kaitannya dengan masing- 
masing bidang fungsional utama perusahaan (Corporate functions, Management information, Research and development, Operations, Product design, Marketing, dan Sales and distribution).

c) Competitive Advantage

Menurut Grant (2010), keuntungan yang diperoleh perusahaan berdasarkan resources dan organizational capabilities tergantung pada kemampuannya dalam membangun, mempertahankan, dan memperoleh keuntungan dari competitive advantage .

\section{Analisis Lingkungan Eksternal PESTLE Analysis}

Menurut Andersen (2013), PEST analysis merupakan penilaian kondisi lingkungan eksogen terkait potensi pengaruh dari politik, ekonomi, sosial, dan teknologi. Seiring dengan banyaknya penelitian yang dilakukan, saat ini PEST analysis berkembang menjadi PESTLE (Political, Economic, Social, Technological, Legal, Environment) analysis.

\section{Porter's Five-Forces Model}

Grant (2010) menyatakan bahwa Porter's five-forces model memandang bahwa profitabilitas sebuah industri ditentukan oleh lima sumber tekanan kompetitif yang terdiri atas 3 sumber kompetisi "horisontal" (Competition from substitutes, Threat of new entry, dan Rivalry between established competitors) serta 2 sumber kompetisi "vertikal" (Bargaining power of buyers, dan Bargaining power of suppliers).

\section{The Competitive Profile Matrix (CPM)}

Menurut David (2015), The CPM digunakan untuk mengidentifikasi pesaing utama perusahaan serta kekuatan dan kelemahan tertentu dalam kaitannya dengan posisi strategis perusahaan yang dijadikan sampel. Critical success factors dalam The CPM mencakup isu internal dan eksternal. Peringkat yang diberikan dalam The CPM didasarkan pada kekuatan dan kelemahan perusahaan $(4=$ kekuatan utama, $3=$ kekuatan minor, $2=$ kelemahan minor, dan $1=$ kelemahan utama).

\section{The Strengths-Weaknesses-Opportunities- Threats (SWOT) Matrix}

Menurut David (2015), The StrengthsWeaknesses-Opportunities-Threats

(SWOT)

Matrix merupakan matching tool yang penting dalam membantu manajer mengembangkan 4 tipe strategi: SO (Strengths-Opportunities) Strategies, WO (Weaknesses-Opportunities) Strategies, ST (Strengths-Threats) Strategies, dan WT (Weaknesses-Threats) Strategies. SO Strategies merupakan strategi yang menggunakan kekuatan internal perusahaan untuk mengambil keuntungan berdasarkan kesempatan dari luar. WO Strategies merupakan strategi yang memperbaiki kelemahan internal dengan cara mengambil keuntungan berdasarkan kesempatan dari luar. ST Strategies merupakan strategi yang menggunakan kekuatan perusahaan untuk menghindari atau mengurangi dampak ancaman dari luar. WT Strategies merupakan taktik pertahanan untuk mengurangi kelemahan internal dan menghindari ancaman dari luar.

\section{METODOLOGI}

\section{Objek Penelitian}

Penelitian dilakukan di PT. $X$ yang berlokasi di Bandung, Jawa Barat. PT. X merupakan perusahaan yang berdiri sejak tahun 1990. Alur penjualan barang dari dan ke PT. X dapat dilihat pada Gambar 4. Saat ini PT. X tidak memiliki visi dan misi perusahaan. Tujuan dari pemiliklah yang menjadi acuan pemilik dalam menjalankan perusahaan, dimana tujuan tersebut terbagi atas tujuan jangka panjang (menjadikan PT. $\mathrm{X}$ sebagai perusahaan distributor furniture yang memiliki banyak cabang) dan tujuan jangka pendek (menjadikan PT. X sebagai perusahaan dengan omset yang stabil).

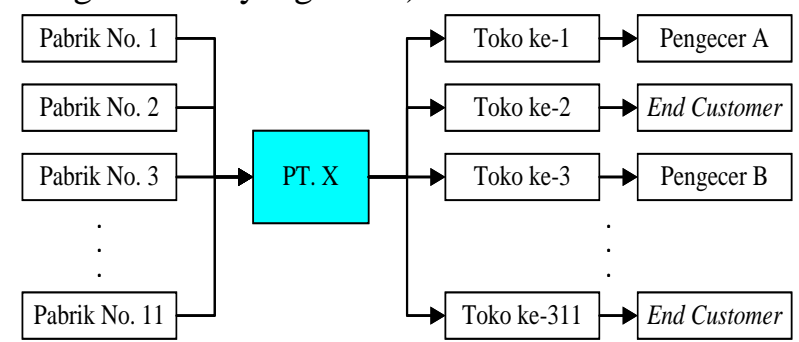

Gambar 4. Skema Penjualan Barang PT. X

Sumber: Diolah dari Hasil Wawancara dengan Pihak PT. X 


\section{Metode Penelitian}

Silalahi (2009) menyatakan bahwa "metode penelitian merupakan cara dan prosedur yang sistematis dan terorganisasi untuk menyelidiki suatu masalah tertentu dengan maksud mendapatkan informasi untuk digunakan sebagai solusi atas masalah tersebut". Menurut Silalahi (2009), ada 2 jenis metode penelitian, yaitu: Metode penelitian kuantitatif, dan Metode penelitian kualitatif. Metode penelitian yang digunakan dalam penelitian ini adalah metode penelitian kualitatif (karena penelitian ini menggunakan data yang terkumpul dari pihak PT. $\mathrm{X}$ secara lisan dan terperinci, dimana data tersebut kemudian diolah mengikuti teori yang sesuai dengan keadaan PT. X) dan metode penelitian kuantitatif untuk menganalis hasil kuesioner.

\section{Tipe Penelitian}

Menurut Sekaran (2010) ada 2 tipe penelitian berdasarkan tujuannya, yaitu: Applied research, dan Basic research. Tipe penelitian yang sesuai dengan penelitian ini adalah applied research karena penelitian ini dilakukan khusus untuk mengatasi permasalahan yang terjadi di PT. X. Silalahi (2009) membagi penelitian menjadi 3 tipe berdasarkan tujuannya, yaitu: Penelitian eksploratori, Penelitian deskriptif, dan Penelitian eksplanatori. Tipe penelitian yang paling sesuai untuk penelitian ini adalah penelitian deskriptif. Hal ini dikarenakan penelitian ini menggambarkan secara detail permasalahan yang terjadi di PT. X menggunakan data yang sesuai dengan fakta yang ada di lapangan.

\section{Sumber Data}

Pada penelitian ini digunakan primary data (melalui hasil wawancara dan observasi langsung dengan pihak PT. X, serta melalui hasil kuesioner yang dibagikan kepada konsumen PT. $\mathrm{X})$ dan secondary data (melalui dokumendokumen perusahaan, data-data dari Badan Pusat Statistik, serta internet).

Kuesioner dibagikan dengan menggunakan metode sampling, dimana: populasi pada penelitian ini merupakan keseluruhan konsumen PT. X yang terdiri atas 311 toko, sample frame dalam penelitian ini adalah data konsumen
PT. X, penelitian ini menggunakan nonprobability sampling karena pembagian kuesioner dilakukan tergantung toko mana saja yang didatangi oleh staf penjualan sehingga tidak semua toko berpeluang menjadi sampel, tipe nonprobability sampling yang sesuai dengan penelitian ini adalah purposive sampling karena sampel penelitian terbatas pada konsumen PT. X yang mengetahui tentang Pesaing A dan Pesaing B. Sekaran (2010) menyatakan bahwa dalam purposive sampling, "the sampling here is confined to specific types of people who can provide the desired information, either because they are the only ones who have it, or conform to some criteria set by the researcher".

Silalahi (2009) menyatakan bahwa "untuk penelitian deskriptif, sampel $10 \%$ dari populasi dianggap sebagai jumlah paling minimal". Karena penelitian ini adalah penelitian deskriptif, maka jumlah sampel minimal dalam penelitian ini sebesar $10 \%$ dari total populasi (311 toko), yaitu sebanyak 31,1 responden atau 32 responden. Ada 48 kuesioner yang diolah dalam penelitian ini. Jumlah tersebut dianggap cukup untuk penelitian ini karena sudah melebihi jumlah sampel minimal penelitian.

\section{Metode Pengumpulan Data}

Silalahi (2009) menjelaskan bahwa "metode pengumpulan data adalah cara yang dapat digunakan untuk mengumpulkan atau mendapatkan data dari fenomena empiris". Menurut Sekaran (2010), ada 3 metode utama dalam pengumpulan data, yaitu: interviewing, questionnaires, dan observing people and phenomena.

Penelitian ini melakukan metode wawancara baik secara terstruktur (sudah dibuat susunan pertanyaan sebelumnya) maupun tidak terstruktur (muncul saat proses wawancara terkait jawaban dari pihak yang diwawancara). Pelaksanaan wawancara dalam penelitian ini dilakukan melalui tatap muka dan telepon. Hal ini disesuaikan dengan kondisi dari peneliti dan pihak PT. $X$ yang diwawancara. Narasumber yang diwawancara adalah pemilik PT. X (Direktur PT. $\mathrm{X}$ ), serta Kepala Administrasi Umum, Pengawasan dan Pergudangan PT. X. 
Penelitian ini menggunakan tipe kuesioner pertanyaan tertutup kepada konsumen PT. X agar penelitian terfokus pada pokok permasalahan serta kuesioner pertanyaan terbuka untuk mendapat informasi yang tidak tercantum dari kuesioner pertanyaan tertutup. Kuesioner menggunakan rating scale betipe likert scale dengan skala interval. Pada penelitian ini juga dilakukan observasi terkait kondisi PT. X serta laju pertumbuhan ekonomi di Indonesia dan di wilayah Jawa Barat yang didapatkan dari laporan Badan Pusat Statistik.

\section{Pengolahan Data}

Menurut Silalahi (2009), "pengolahan data adalah proses mentransformasi (menyederhanakan dan mengorganisasi) data mentah ke dalam bentuk yang mudah dibaca dan dipahami”. Data yang didapatkan berdasarkan hasil kuesioner yang telah dibagikan kepada konsumen PT. X akan diuji terlebih dahulu menggunakan uji validitas dan uji reliabilitas menggunakan software IBM SPSS Statistics 23. Pengolahan data ini mengacu pada operasionalisasi variabel (Tabel 2) yang menjadi dasar dalam pertanyaan kuesioner.

\section{Uji Validitas}

Menurut Sekaran (2010), "Validity establishes how well a technique, instrument, or process measures a particular concept". Teknik Pearson Product Moment Correlation (r) cocok digunakan dalam uji validitas penelitian ini karena kuesioner penelitian menggunakan skala interval. Hasil uji validitas (Tabel 3) menunjukkan bahwa semua item dalam setiap variabel untuk marketing mix PT. X, Pesaing A, dan Pesaing B dalam kuesioner bernilai lebih dari R Tabel (0.2403) sehingga dinyatakan bahwa semua item valid. Oleh karena itu semua item dapat digunakan untuk pengujian selanjutnya, yaitu uji reliabilitas.
Tabel 2. Operasionalisasi Variabel

\begin{tabular}{|c|c|c|}
\hline Variabel & Dimensi & Indikator \\
\hline \multirow{28}{*}{$\begin{array}{l}\text { Marketing } \\
\text { Mix }\end{array}$} & \multirow{6}{*}{ Produk } & Variasi produk \\
\hline & & Kualitas produk \\
\hline & & Daya tahan produk \\
\hline & & Garansi produk \\
\hline & & $\begin{array}{l}\text { Kesesuaian dengan } \\
\text { kebutuhan konsumen }\end{array}$ \\
\hline & & $\begin{array}{l}\text { Frekuensi penggunaan } \\
\text { produk }\end{array}$ \\
\hline & \multirow{5}{*}{ Harga } & $\begin{array}{l}\text { Kesesuaian dengan kualitas } \\
\text { produk }\end{array}$ \\
\hline & & Daya saing harga \\
\hline & & Kekonsistenan harga \\
\hline & & Ketentuan pembayaran \\
\hline & & Periode pembayaran \\
\hline & \multirow{3}{*}{ Lokasi } & Kemudahan akses \\
\hline & & Kestrategisan lokasi \\
\hline & & Kadar kemacetan \\
\hline & \multirow{4}{*}{ Promosi } & $\begin{array}{l}\text { Kesesuaian dengan minat } \\
\text { pembeli }\end{array}$ \\
\hline & & Penggunaan teknologi \\
\hline & & $\begin{array}{l}\text { Kemudahan penggunaan } \\
\text { katalog }\end{array}$ \\
\hline & & Kelengkapan katalog \\
\hline & \multirow{3}{*}{ Karyawan } & $\begin{array}{l}\text { Kemampuan melakukan } \\
\text { promosi }\end{array}$ \\
\hline & & Keramahan karyawan \\
\hline & & Kepekaan karyawan \\
\hline & \multirow{3}{*}{ Bukti Fisik } & $\begin{array}{l}\text { Keteraturan tata letak } \\
\text { barang }\end{array}$ \\
\hline & & $\begin{array}{l}\text { Kondisi kendaraan } \\
\text { pengantar barang }\end{array}$ \\
\hline & & $\begin{array}{l}\text { Kondisi dus yang diterima } \\
\text { konsumen }\end{array}$ \\
\hline & \multirow{4}{*}{ Proses } & $\begin{array}{l}\text { Kemudahan prosedur } \\
\text { pemesanan }\end{array}$ \\
\hline & & $\begin{array}{l}\text { Kemudahan pengembalian } \\
\text { produk (retur) }\end{array}$ \\
\hline & & $\begin{array}{l}\text { Ketepatan waktu dalam } \\
\text { pengiriman barang }\end{array}$ \\
\hline & & $\begin{array}{l}\text { Kecepatan dalam merespon } \\
\text { komplain }\end{array}$ \\
\hline
\end{tabular}


Tabel 3. Hasil Uji Validitas

\begin{tabular}{|c|c|c|c|c|c|c|c|c|}
\hline Variabel & Item & $\begin{array}{c}\mathbf{R} \\
\text { Tabel }\end{array}$ & $\begin{array}{l}\text { Hasil } \\
\text { SPSS } \\
\text { PT. X } \\
\end{array}$ & Kesimpulan & $\begin{array}{c}\text { Hasil SPSS } \\
\text { Pesaing A }\end{array}$ & Kesimpulan & $\begin{array}{c}\text { Hasil SPSS } \\
\text { Pesaing B }\end{array}$ & Kesimpulan \\
\hline \multirow{6}{*}{ Produk } & Produk 1 & 0,2403 & 0,691 & Valid & 5,37 & Valid & 0,444 & Valid \\
\hline & Produk 2 & 0,2403 & 0,571 & Valid & 4,07 & Valid & 0,373 & Valid \\
\hline & Produk 3 & 0,2403 & 0,386 & Valid & 5,09 & Valid & 0,451 & Valid \\
\hline & Produk 4 & 0,2403 & 0,449 & Valid & 4,33 & Valid & 0,293 & Valid \\
\hline & Produk 5 & 0,2403 & 0,588 & Valid & 4,37 & Valid & 0,511 & Valid \\
\hline & Produk 6 & 0,2403 & 0,285 & Valid & 4,53 & Valid & 0,309 & Valid \\
\hline \multirow{5}{*}{ Harga } & Harga 1 & 0,2403 & 0,673 & Valid & 0,515 & Valid & 0,549 & Valid \\
\hline & Harga 2 & 0,2403 & 0,589 & Valid & 0,301 & Valid & 0,259 & Valid \\
\hline & Harga 3 & 0,2403 & 0,476 & Valid & 0,373 & Valid & 0,591 & Valid \\
\hline & Harga 4 & 0,2403 & 0,659 & Valid & 0,343 & Valid & 0,716 & Valid \\
\hline & Harga 5 & 0,2403 & 0,319 & Valid & 0,403 & Valid & 0,388 & Valid \\
\hline \multirow{3}{*}{ Lokasi } & Lokasi 1 & 0,2403 & 0,834 & Valid & 0,602 & Valid & 0,532 & Valid \\
\hline & Lokasi 2 & 0,2403 & 0,831 & Valid & 0,655 & Valid & 0,635 & Valid \\
\hline & Lokasi 3 & 0,2403 & 0,697 & Valid & 0,323 & Valid & 0,3 & Valid \\
\hline \multirow{4}{*}{ Promosi } & Promosi 1 & 0,2403 & 0,479 & Valid & 0,523 & Valid & 0,479 & Valid \\
\hline & Promosi 2 & 0,2403 & 0,47 & Valid & 0,335 & Valid & 0,397 & Valid \\
\hline & Promosi 3 & 0,2403 & 0,479 & Valid & 0,452 & Valid & 0,583 & Valid \\
\hline & Promosi 4 & 0,2403 & 0,517 & Valid & 0,405 & Valid & 0,547 & Valid \\
\hline \multirow{3}{*}{ Karyawan } & $\begin{array}{l}\text { Karyawan } \\
1\end{array}$ & 0,2403 & 0,765 & Valid & 0,443 & Valid & 0,468 & Valid \\
\hline & $\begin{array}{l}\text { Karyawan } \\
2\end{array}$ & 0,2403 & 0,63 & Valid & 0,37 & Valid & 0,465 & Valid \\
\hline & $\begin{array}{l}\text { Karyawan } \\
3\end{array}$ & 0,2403 & 0,734 & Valid & 0,694 & Valid & 0,361 & Valid \\
\hline \multirow{3}{*}{ Bukti Fisik } & $\begin{array}{l}\text { Bukti Fisik } \\
1\end{array}$ & 0,2403 & 0,712 & Valid & 0,392 & Valid & 0,369 & Valid \\
\hline & $\begin{array}{l}\text { Bukti Fisik } \\
2\end{array}$ & 0,2403 & 0,302 & Valid & 0,363 & Valid & 0,36 & Valid \\
\hline & $\begin{array}{l}\text { Bukti Fisik } \\
3\end{array}$ & 0,2403 & 0,711 & Valid & 0,607 & Valid & 0,656 & Valid \\
\hline \multirow{4}{*}{ Proses } & Proses 1 & 0,2403 & 0,599 & Valid & 0,733 & Valid & 0,709 & Valid \\
\hline & Proses 2 & 0,2403 & 0,618 & Valid & 0,689 & Valid & 0,629 & Valid \\
\hline & Proses 3 & 0,2403 & 0,509 & Valid & 0,287 & Valid & 0,26 & Valid \\
\hline & Proses 4 & 0,2403 & 0,711 & Valid & 0,524 & Valid & 0,497 & Valid \\
\hline
\end{tabular}

Sumber: Diolah berdasarkan hasil kuesioner

\section{Uji Reliabilitas}

Sekaran (2010) menyatakan "Reliability indicates how stably and consistently the instrument taps the variable". Menurut Sekaran (2010), Cronbach's alpha adalah koefisien reliabilitas yang menunjukkan seberapa baik item berkorelasi positif satu sama lain. Sekaran (2010) menambahkan, "In general, reliabilities less than
0.60 are considered to be poor, those in the 0.70 range, acceptable, and those over 0.80 good". Berdasarkan pernyataan tersebut, maka nilai minimal Cronbach's alpha dalam penelitian ini adalah 0,60. Hasil uji reliabilitas (Tabel 4) menunjukkan bahwa semua variabel marketing mix untuk PT. X, Pesaing A, dan Pesaing B dalam kuesioner memiliki nilai Cronbach's alpha lebih 
Tabel 4. Hasil Uji Reliabilitas

\begin{tabular}{|c|c|c|c|c|c|c|}
\hline \multirow[b]{2}{*}{ Variabel } & \multicolumn{2}{|c|}{ PT. $X$} & \multicolumn{2}{|c|}{ Pesaing A } & \multicolumn{2}{|c|}{ Pesaing B } \\
\hline & $\begin{array}{c}\text { Nilai } \\
\text { Cronbach's } \\
\text { Alpha }\end{array}$ & Kesimpulan & $\begin{array}{c}\text { Nilai } \\
\text { Cronbach's } \\
\text { Alpha }\end{array}$ & Kesimpulan & $\begin{array}{c}\text { Nilai } \\
\text { Cronbach's } \\
\text { Alpha }\end{array}$ & Kesimpulan \\
\hline Produk & 0,732 & Reliabel & 0,716 & Reliabel & 0,64 & Reliabel \\
\hline Harga & 0,746 & Reliabel & 0,609 & Reliabel & 0,7 & Reliabel \\
\hline Lokasi & 0,89 & Reliabel & 0,699 & Reliabel & 0,661 & Reliabel \\
\hline Promosi & 0,687 & Reliabel & 0,641 & Reliabel & 0,706 & Reliabel \\
\hline Karyawan & 0,822 & Reliabel & 0,674 & Reliabel & 0,621 & Reliabel \\
\hline Bukti Fisik & 0,729 & Reliabel & 0,617 & Reliabel & 0,62 & Reliabel \\
\hline Proses & 0,777 & Reliabel & 0,75 & Reliabel & 0,718 & Reliabel \\
\hline
\end{tabular}

dari 0,60 sehingga dinyatakan bahwa semua variabel reliabel. Oleh karena itu semua nilai dalam variabel layak digunakan dalam penelitian ini.

\section{ANALISIS DAN USULAN STRATEGI}

\section{Analisis Strategi Pemasaran Saat Ini Segmenting Perusahaan}

PT. X merupakan perusahaan distributor, oleh karena itu segmenting dari PT. X adalah business market segmenting. Ada 5 kategori dalam segmenting tersebut yang menjadi pertimbangan PT. X, yaitu: Type of Organization, Organizational Characteristics, Benefits Sought or Buying Process, Personal and Psychological Characteristics, dan Relationship Intensity.

\section{Targeting Perusahaan}

PT. X dapat dikatakan menggunakan market specialization (perusahaan memfokuskan pada satu jenis pasar dengan menjual beberapa kategori produk) karena PT. X memfokuskan diri pada pasar menengah kebawah dengan menjual perabot rumah tangga yang terdiri atas 4 kategori produk (lemari pakaian, rak piring, jemuran, dan tangga), dimana masing-masing kategori produk memiliki beberapa variasi produk yang dibutuhkan oleh pasar menengah kebawah. Penjabaran targeting dari kategori dalam segmenting di PT. X dapat dilihat pada Tabel 5. Dengan menggunakan software IBM SPSS Statistics 23, pada penelitian ini dilakukan crosstab terhadap variabel dalam profil responden (umur toko konsumen, omset konsumen per bulan, lama kerjasama dengan PT. $\mathrm{X}$, dan prioritas memilih PT. X) untuk mengetahui pengaruh dari hubungan antar variabel bagi

PT. X. Hasil crosstab dapat dilihat pada Tabel 6 - Tabel 8. Berdasarkan hasil crosstab juga diketahui bahwa ada hubungan antara variabel omset konsumen per bulan dengan umur toko konsumen, variabel omset konsumen per bulan dengan lama kerjasama dengan PT. X, dan variabel omset konsumen per bulan dengan prioritas memilih PT. X.

Berdasarkan Tabel 6 diketahui bahwa toko dengan umur berdiri 16-20 tahun memiliki omset penjualan yang besar. Lama berdirinya toko ada hubungannya dengan jumlah omset konsumen per bulan. Toko dengan usia $6-10$ tahun dan 16-20 tahun dapat PT. X berikan pelayanan yang lebih baik lagi. 
Tabel 5. Targeting PT. X

\begin{tabular}{|c|l|l|}
\hline No. & \multicolumn{1}{|c|}{ Segmenting } & \multicolumn{1}{c}{ Targeting } \\
\hline 1 & $\begin{array}{l}\text { Type of } \\
\text { Organization }\end{array}$ & $\begin{array}{l}\text { Direktur PT. X memilih konsumen berdasarkan produk yang dijual oleh konsumen tersebut. PT. X } \\
\text { memilih toko yang menjual produk pecah belah untuk produk rak piringnya, toko mebel untuk semua } \\
\text { produk rumah tangganya (rak piring, lemari pakaian, jemuran, tangga), dan toko bangunan untuk } \\
\text { produk tangganya. Toko-toko tersebut dipilih menjadi konsumen PT. X karena merupakan toko yang } \\
\text { masih dalam bidang penjualan yang sama dengan PT. X, yaitu perabot rumah tangga. }\end{array}$ \\
\hline 2 & $\begin{array}{l}\text { Organizational } \\
\text { Characteristics }\end{array}$ & $\begin{array}{l}\text { PT. X melihat omset penjualan serta kemampuan pembayaran dari konsumen. Direktur PT. X } \\
\text { mencari konsumen yang memiliki omset penjualan yang cukup tinggi (Rp 20.000.000 - Rp } \\
60.000 .0000 \text { per bulan) dengan kemampuan pembayaran yang baik (informasi ini diketahui } \\
\text { berdasarkan info rekanan PT. X). Selain itu, PT. X mencari konsumen yang berlokasi di Pulau Jawa. }\end{array}$ \\
\hline 3 & $\begin{array}{l}\text { Benefits Sought or } \\
\text { Buying Process }\end{array}$ & $\begin{array}{l}\text { Direktur PT. X mencari konsumen yang membutuhkan produk berkualitas dengan harga rendah, } \\
\text { dimana proses pembelian dapat dilakukan secara fleksibel, sesuai dengan kebutuhan konsumen. }\end{array}$ \\
\hline 4 & $\begin{array}{l}\text { Personal and } \\
\text { Psychological } \\
\text { Characteristics }\end{array}$ & $\begin{array}{l}\text { Konsumen yang diinginkan oleh PT. X adalah toko yang baru berdiri atau sudah lama berdiri dalam } \\
\text { bidang perabot rumah tangga, dimana rentang usia toko kurang dari 1 tahun hingga 21 tahun. Selain } \\
\text { itu, PT. X menginginkan konsumen yang memiliki koneksi bisnis yang luas yang terdiri atas rekanan } \\
\text { toko dan keluarga konsumen. }\end{array}$ \\
\hline 5 & $\begin{array}{l}\text { Relationship } \\
\text { Intensity }\end{array}$ & $\begin{array}{l}\text { PT. X mencari konsumen yang loyal (dapat bekerjasama 6 - 10 tahun lamanya, menjadikan PT. X } \\
\text { sebagai prioritas 3 besar untuk diajak kerjasama). Agar dapat memastikan kebutuhan tiap konsumen } \\
\text { terpenuhi dengan tepat maka staf penjualan yang memegang konsumen tersebut tidak akan berubah } \\
\text { kecuali jika staf tersebut resign. }\end{array}$ \\
\hline
\end{tabular}

Sumber: Diolah Berdasarkan Hasil Wawancara, Observasi dan Kuesioner

Tabel 6. Crosstab Omset Konsumen per Bulan VS Umur Toko Konsumen

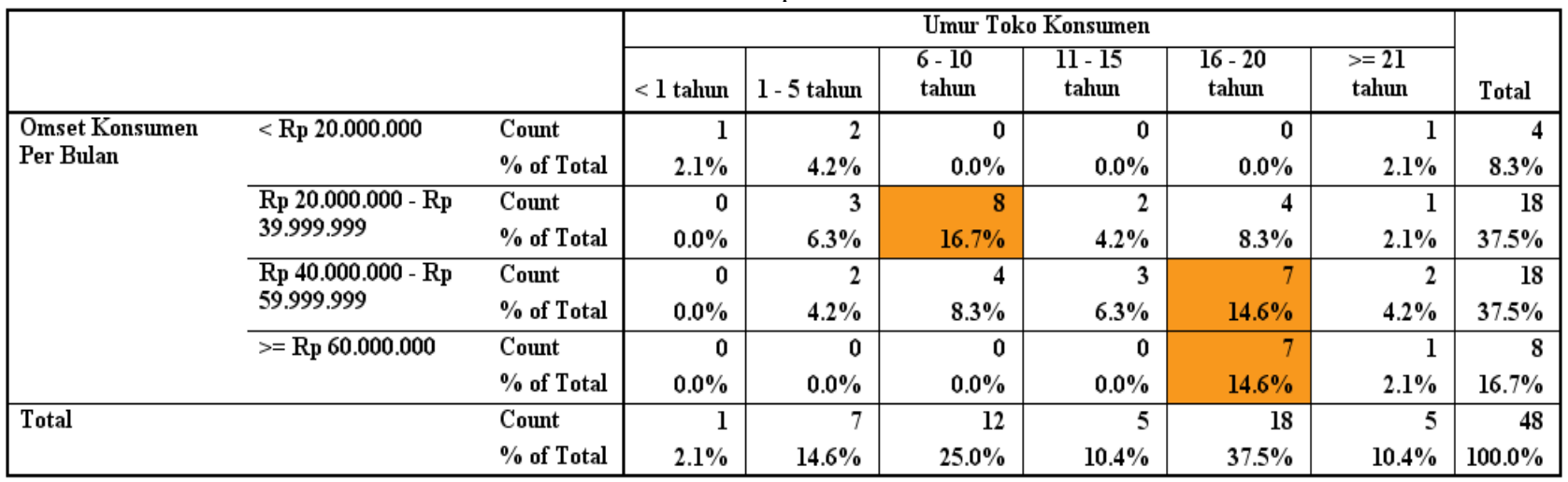

Sumber: Diolah Berdasarkan Hasil IBM SPSS Statistics 23

Tabel 7. Crosstab Omset Konsumen per Bulan VS Lama Kerjasama dengan PT. X

\begin{tabular}{|c|c|c|c|c|c|c|c|c|c|}
\hline & \multicolumn{6}{|c|}{ Lama Kerjasama dengan PT X } & \multirow[b]{2}{*}{ Total } \\
\hline & & & $<1$ tahun & 1 - 5 tahun & $\begin{array}{l}6-10 \\
\text { tahun }\end{array}$ & $\begin{array}{r}11-15 \\
\text { tahun }\end{array}$ & $\begin{array}{c}16-20 \\
\text { tahun }\end{array}$ & $\begin{array}{l}>=21 \\
\text { tahun }\end{array}$ & \\
\hline \multirow{8}{*}{$\begin{array}{l}\text { Omset Konsumen } \\
\text { Per Bulan }\end{array}$} & \multirow[t]{2}{*}{$<\mathrm{Rp} 20.000 .000$} & Count & 2 & 2 & 0 & 0 & 0 & $\overline{0}$ & $\overline{4}$ \\
\hline & & $\%$ of Total & $4.2 \%$ & $4.2 \%$ & $0.0 \%$ & $0.0 \%$ & $0.0 \%$ & $0.0 \%$ & $8.3 \%$ \\
\hline & \multirow{2}{*}{$\begin{array}{l}\text { Rp 20.000.000 - Rp } \\
39.999 .999\end{array}$} & Count & 0 & 1 & 10 & 6 & 1 & 0 & 18 \\
\hline & & $\%$ of Total & $0.0 \%$ & $2.1 \%$ & $20.8 \%$ & $12.5 \%$ & $2.1 \%$ & $0.0 \%$ & $37.5 \%$ \\
\hline & \multirow{2}{*}{$\begin{array}{l}\text { Rp 40.000.000 - Rp } \\
59.999 .999\end{array}$} & Count & 1 & 6 & 2 & 3 & 4 & 2 & 18 \\
\hline & & $\%$ of Total & $2.1 \%$ & $12.5 \%$ & $4.2 \%$ & $6.3 \%$ & $8.3 \%$ & $4.2 \%$ & $37.5 \%$ \\
\hline & \multirow[t]{2}{*}{$>=\mathrm{Rp} 60.000 .000$} & Count & 1 & 2 & 1 & 3 & 1 & 0 & 8 \\
\hline & & $\%$ of Total & $2.1 \%$ & $4.2 \%$ & $2.1 \%$ & $6.3 \%$ & $2.1 \%$ & $0.0 \%$ & $16.7 \%$ \\
\hline \multirow[t]{2}{*}{ Total } & & Count & 4 & 11 & 13 & 12 & 6 & 2 & 48 \\
\hline & & $\%$ of Total & $8.3 \%$ & $22.9 \%$ & $27.1 \%$ & $25.0 \%$ & $12.5 \%$ & $4.2 \%$ & $100.0 \%$ \\
\hline
\end{tabular}

Sumber: Diolah Berdasarkan Hasil IBM SPSS Statistics 23 
Tabel 8. Crosstab Omset Konsumen per Bulan VS Prioritas Memilih PT. X

\begin{tabular}{|c|c|c|c|c|c|c|c|}
\hline & & & \multicolumn{4}{|c|}{ Prioritas Memilih PT X } & \multirow[b]{2}{*}{ Total } \\
\hline & & & Pertama & Kedua & Ketiga & Lainnya & \\
\hline \multirow{8}{*}{$\begin{array}{l}\text { Omset Konsumen } \\
\text { Per Bulan }\end{array}$} & \multirow[t]{2}{*}{$<$ Rp 20.000.000 } & Count & 3 & 0 & $\mathbf{1}$ & o & 4 \\
\hline & & $\%$ of Total & $6.3 \%$ & $0.0 \%$ & $2.1 \%$ & $0.0 \%$ & $8.3 \%$ \\
\hline & \multirow{2}{*}{$\begin{array}{l}\text { Rp 20.000.000 - Rp } \\
39.999 .999\end{array}$} & Count & 2 & o & 7 & 9 & 18 \\
\hline & & $\%$ of Total & $4.2 \%$ & $0.0 \%$ & $14.6 \%$ & $18.8 \%$ & $37.5 \%$ \\
\hline & \multirow{2}{*}{$\begin{array}{l}\text { Rp 40.000.000 - Rp } \\
59.999 .999\end{array}$} & Count & 10 & 3 & 3 & 2 & 18 \\
\hline & & $\%$ of Total & $20.8 \%$ & $6.3 \%$ & $6.3 \%$ & $4.2 \%$ & $37.5 \%$ \\
\hline & \multirow[t]{2}{*}{$>=\operatorname{Rp} 60.000 .000$} & Count & 5 & 1 & 1 & $\mathbf{l}$ & 8 \\
\hline & & $\%$ of Total & $10.4 \%$ & $2.1 \%$ & $2.1 \%$ & $2.1 \%$ & $16.7 \%$ \\
\hline \multirow[t]{2}{*}{ Total } & & Count & 20 & 4 & 12 & 12 & 48 \\
\hline & & $\%$ of Total & $41.7 \%$ & $8.3 \%$ & $25.0 \%$ & $25.0 \%$ & $100.0 \%$ \\
\hline
\end{tabular}

Sumber: Diolah Berdasarkan Hasil IBM SPSS Statistics 23

Berdasarkan Tabel 7 diketahui bahwa PT. $\mathrm{X}$ memiliki potensi untuk meningkatkan penjualan dengan konsumen yang sudah bekerjasama dengan PT. X selama $1-5$ tahun, 6 - 10 tahun, dan $11-$ 15 tahun karena konsumen tersebut memiliki potensi besar dalam penjualan PT. X.

Berdasarkan Tabel 8 diketahui bahwa bagi konsumen yang menempatkan PT. X sebagai prioritas pertama untuk diajak kerjasama (sebanyak 20 toko atau 41,7\%), PT. X sebaiknya memberikan prioritas dalam hal penawaran produk-produk baru, pengiriman, serta kelonggaran periode pembayaran, khususnya bagi 10 konsumen (20.8\%) yang memiliki omset per bulan sebesar Rp 40.000.000 - Rp 59.999.999, dan diharapkan PT. X dapat memberikan pelayanan lebih baik pada toko-toko tersebut.

\section{Positioning Perusahaan}

Direktur PT. X menginginkan citra perusahaan sebagai distributor yang menjual produk berkualitas dengan harga yang murah. Berdasarkan hasil kuesioner, diketahui bahwa para konsumen setuju bahwa PT. X memiliki citra yang demikian.

\section{Marketing Mix (7P) Perusahaan}

PT. X merupakan perusahaan jasa karena PT. X adalah distributor yang bertindak sebagai perantara penjualan dan pemasaran produk dari produsen ke konsumen. Berdasarkan hasil kuesioner diketahui bahwa sebagian besar konsumen PT. X menjawab bahwa pemasaran PT. $\mathrm{X}$ secara keseluruhan bernilai baik. Sisanya menjawab cukup baik dan tidak ada yang menjawab bahwa pemasaran PT. X tidak baik. Hasil rekapitulasi rata-rata nilai marketing mix (bauran pemasaran) yang dimiliki oleh PT. X, Pesaing A, dan Pesaing B dapat dilihat pada Gambar 4. Marketing mix tersebut terdiri atas: product (produk), price (harga), place (lokasi), promotion (promosi), people (karyawan), physical evidence (bukti fisik), dan process (proses). 


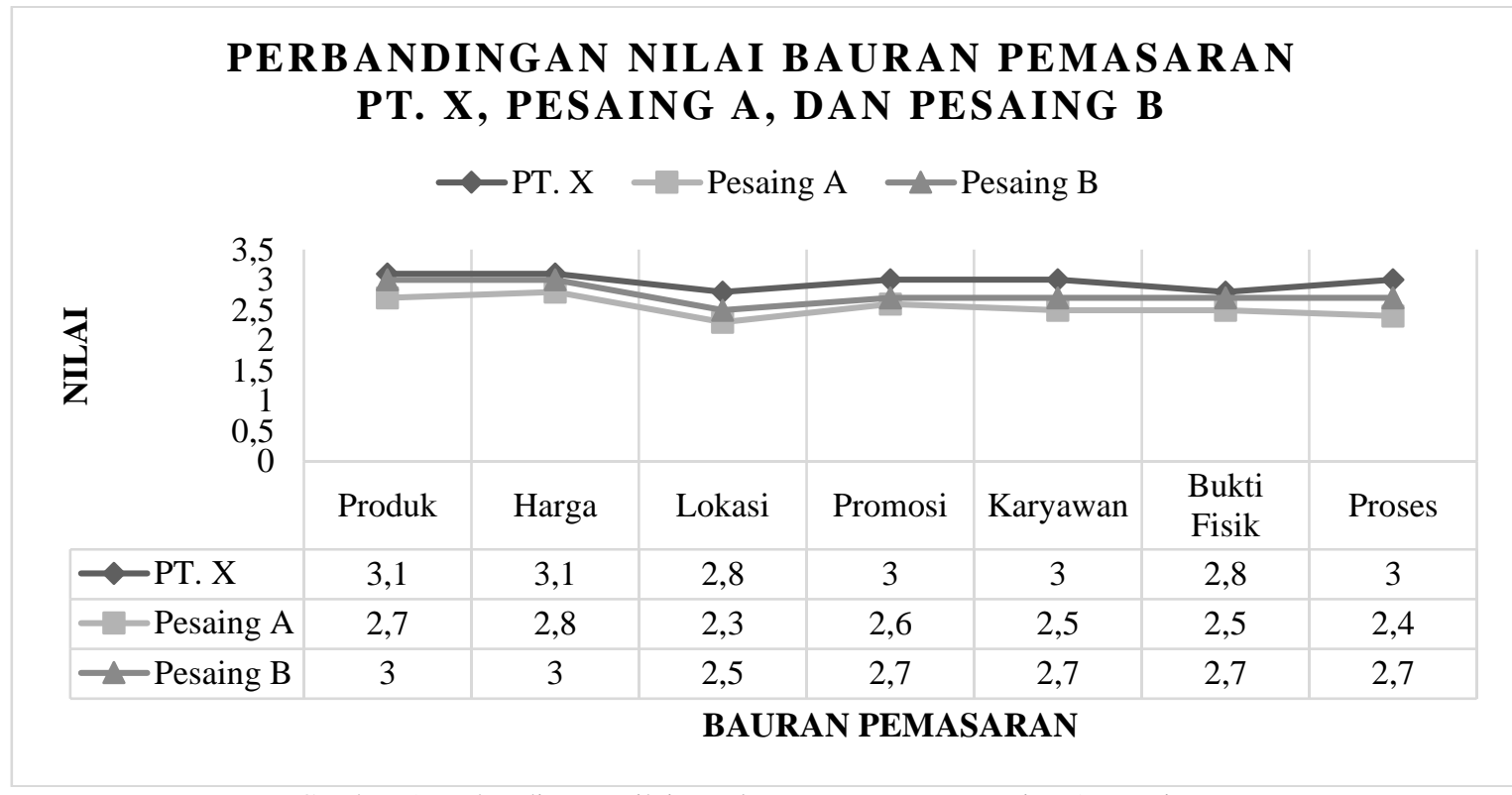

Gambar 5. Perbandingan Nilai Marketing Mix PT. X, Pesaing A, Pesaing B Sumber: Diolah Berdasarkan Hasil Kuesioner (Skala 1 -4)

\section{Analisis Internal Perusahaan}

Resources Perusahaan

Pada bagian resources ada 3 hal yang dianalisis, yaitu

\section{a) Tangible resources}

Terdiri atas: Financial resources (berupa kas kecil, utang, modal), dan Physical resources (berupa perlengkapan yang ada di kantor dan gudang).

b) Intangible resources

Terdiri atas Reputation resources, yaitu: brand dari produk yang dijual, serta hubungan baik yang terjalin antara konsumen dengan PT. X.

c) Human resources

PT. X menerima para staf dengan lulusan minimal SMA serta untuk supir dan kenek tidak ada acuan minimum. Kepala Administrasi Umum, Pengawasan dan Pergudangan PT. X menambahkan bahwa hal tersebut menjadi penyebab seringnya terjadi miscommunication antar pegawai. Selain itu, terbatasnya jumlah pegawai yang dimiliki membuat beberapa staf memiliki beban tugas yang berlebih sehingga deadline tugas yang diberikan kepada pegawai tersebut tidak terpenuhi. Meskipun demikian, Direktur PT. X masih memberikan toleransi atas keterlambatan deadline tersebut.

\section{Capabilities Perusahaan}

Area fungsional yang dianalisis dalam penelitian ini adalah area marketing (pemasaran) serta sales and distribution (penjualan dan distribusi).

\section{Competitive Advantage Perusahaan}

Competitive advantage PT. X terletak pada harga yang murah (low cost) dan pelayanan yang cepat. PT. X dapat memberikan harga yang murah kepada konsumen karena PT. X merupakan pemasok pertama dari pabrik. Pelayanan PT. X cepat karena PT. X mengadakan persediaan yang banyak untuk produk-produk yang banyak dicari konsumen sehingga jika pesanan masuk, konsumen akan mendapatkan produk yang dipesan keesokan harinya. PT. X dapat menyimpan banyak persediaan karena produk yang dijual tahan lama (produk terbuat dari plastik, aluminium, dan besi).

\section{PESTLE Analysis \\ Political Factor}

Faktor politik yang berpengaruh pada PT. $\mathrm{X}$ adalah faktor pemilu, dimana permintaan konsumen PT. X menurun saat mendekati hari pemilu dan pada hari pemilu pengiriman tidak dapat dilakukan. Hal tersebut dikarenakan maraknya demo yang terjadi pada saat musim pemilu. 


\section{Economic Factor}

Faktor ekonomi yang berpengaruh pada PT. X adalah fluktuasi harga dari produsen, lemahnya daya beli masyarakat yang terlihat dari laju pertumbuhan PDB meskipun inflasi menurun, pertumbuhan ekonomi di wilayah pemasaran PT. $\mathrm{X}$, serta tingkat suku bunga dan limit pinjaman kredit dari bank.

\section{Social Factor}

Permintaan produk PT. X mengalami fluktuasi setiap bulannya. Kepala Administrasi Umum, Pengawasan dan Pergudangan PT. X mengatakan bahwa permintaan produk akan meningkat pada saat awal bulan, musim panen, dan saat para pegawai negeri menerima gaji ketigabelas. Penurunan permintaan terjadi saat akhir bulan, lebaran haji, tahun ajaran baru, dan terutama pada saat lebaran Idul Fitri.

\section{Technological Factor}

Saat ini penggunaan teknologi yang terlihat di PT. X hanyalah penggunaan komputer (program Microsoft Excel dan Microsoft Word), serta penggunakan WhatsApp (WA) sebagai sarana komunikasi antara PT. X dengan konsumennya. Berdasarkan hasil kuesioner dan dengan melihat data Kementrian Komunikasi dan Informatika Republik Indonesia, diketahui bahwa rentang usia konsumen PT. X termasuk dalam rentang usia pengguna internet di Indonesia. Oleh karena itu PT. $\mathrm{X}$ memiliki peluang untuk menggunakan internet sebagai media pemasarannya.

\section{Legal Factor}

Direktur PT. X meyatakan bahwa tidak ada kebijakan pemerintah yang berpengaruh secara signifikan terhadap perusahaan, bahkan pada saat perusahaan mengganti bentuk badan usahanya dari Persekutuan Komanditer (CV) menjadi Perseroan Terbatas (PT). Meskipun ada peraturan pemerintah terkait pemberian gaji dengan minimal Upah Minimum Regional (UMR), masih ada pegawai PT. X yang gajinya dibawah UMR, seperti: supir dan kenek. Peraturan pemerintah yang paling mendapat perhatian oleh PT. X adalah terkait Tax Amnesti, dimana akhirnya PT. X mendaftar sebagai Perusahaan Kena Pajak (PKP).

\section{Environment Factor}

Tidak ada isu lingkungan yang mempengaruhi PT. X karena PT. X hanya mengeluarkan limbah berupa kardus bekas.

\section{Analisis Porter's Five Forces Model Competition from Substitutes}

PT. X memiliki 4 jenis produk, dimana produk pengganti untuk masing-masing produk berbeda (lihat Tabel 9). Meskipun produk-produk yang dijual oleh PT. X memiliki substitusi (produk pengganti), tetapi Kepala Administrasi Umum, Pengawasan dan Pergudangan PT. X menyatakan bahwa produk-produk pengganti tersebut tidak memiliki pengaruh terhadap penjualan PT. X. Oleh karena itu competition from substitutes yang dihadapi PT. X rendah.

Tabel 9. Daftar Produk Pengganti PT. X

\begin{tabular}{|c|l|l|}
\hline No. & \multicolumn{1}{|c|}{ Produk PT. X } & \multicolumn{1}{c|}{ Produk Pengganti } \\
\hline 1 & Lemari pakaian plastik & Lemari pakaian kayu \\
\hline 2 & Rak piring alumunium & Rak piring plastik \\
\hline 3 & Jemuran besi & $\begin{array}{l}\text { Jemuran plasik, Tali } \\
\text { jemuran }\end{array}$ \\
\hline 4 & Tangga besi & Tangga bambu \\
\hline \multicolumn{3}{|c|}{ Xumber: Diolah dari Hasil Wawancara dengan Direktur PT. } \\
\hline
\end{tabular}

\section{Threat of New Entry}

Menurut Kepala Administrasi Umum, Pengawasan dan Pergudangan PT. X, jika suatu perusahaan hendak memulai usaha sebagai distributor mebel, modal yang dimiliki harus besar. Selain itu, jika sebuah perusahaan distributor ingin mendapat prioritas dalam pengiriman barang dari produsen, perusahaan tersebut harus melakukan perjanjian Delivery Order (DO). Kepala Administrasi Umum, Pengawasan dan Pergudangan PT. X mengatakan bahwa saat ini, untuk wilayah Bandung belum pernah ada perusahaan distributor baru yang benar-benar merintis usahanya dari nol. Oleh karena itu threat of new entry yang dihadapi PT. X rendah.

\section{Rivalry Between Established Competitors}

Ada 2 jenis pesaing bagi PT. X, yaitu: pesaing dari wilayah Bandung dan pesaing dari luar wilayah Bandung. Karena industri distribusi termasuk dalam pasar monopoli atau pasar 
oligopoli, maka dalam 1 wilayah hanya terdapat 1 - 3 distributor untuk 1 merek produk. Persaingan yang terjadi antara PT. X dengan pesaing dari wilayah Bandung adalah persaingan harga dan sistem paket. Sedangkan persaingan dengan pesaing dari luar wilayah Bandung adalah persaingan harga. Direktur PT X mengatakan bahwa PT. X memiliki keunggulan dibanding pesaing dalam 3 hal, yaitu: harga yang murah, PT. $\mathrm{X}$ sebagai distributor tunggal, dan kecepatan pelayanan kepada konsumen PT. X. Oleh karena itu rivalry between established competitor yang dihadapi PT. X sedang.

\section{Bargaining Power of Buyers}

Saat ini konsumen besar PT. X (konsumen yang dalam sebulan rata-rata membeli produk sebanyak Rp 100.000.000 - Rp 120.000.000 atau sebanyak 300 unit) berjumlah 30 toko dan konsumen kecil PT. X (konsumen yang dalam sebulan rata-rata membeli produk sebanyak $\mathrm{Rp}$ 5.000.000 - Rp 30.000.000 atau sebanyak 15 - 30 unit) berjumlah 281 toko. Karena PT. X sudah berdiri selama 25 tahun, maka konsumen PT. X banyak yang merupakan konsumen lama dan loyal. Oleh karena itu bargaining power of buyer yang dihadapi PT. X rendah.

\section{Bargaining Power of Suppliers}

PT. X memiliki 11 supplier yang terdiri atas supplier besar (produsen merek Club, Master, dan Mascot) dan supplier kecil (produsen merek Bina Karya, Galaxy, Matsuo, Akako, Naiba, USA, Arion, dan Nasional). PT. X merupakan distributor tunggal untuk merek Club, Master, dan Mascot. Selain itu, PT. X juga sudah melakukan perjanjian DO dengan produsen merek Club dan Galaxy. Direktur PT. X berusaha memastikan kepuasan supplier besar terhadap omset yang dihasilkan oleh PT. X agar supplier tersebut tidak mencari perusahaan baru untuk diajak kerjasama. Sedangkan terhadap supplier kecilnya, PT. X bisa saja menghentikan kerjasama jika produk yang dihasilkan supplier tersebut tidak menarik lagi bagi konsumen. Oleh karena itu bargaining power of supplier yang dihadapi PT. X sedang.

\section{The Competitive Profile Matrix (CPM)}

Critical success factors dalam penelitian ini adalah marketing mix dari setiap perusahaan (PT. X, Pesaing A, Pesaing B). Oleh karena itu faktorfaktor yang dipertimbangkan ada 7 , yaitu: produk (product), harga (price), lokasi (place), promosi (promotion), karyawan (people), bukti fisik (physical evidence), proses (process). Nilai weight dan rating untuk masing-masing faktor didapatkan dari hasil kuesioner. The CPM penelitian ini dapat dilihat pada Tabel 8. Critical success factors yang ada pada Tabel 10 telah diurutkan berdasarkan weight, dimana weight tersebut menunjukkan seberapa penting nilai critical success factors bagi konsumen dalam memilih distributor. Nilai weigth dan rating berasal dari hasil kuesioner konsumen PT.X. Ada 5 faktor utama yang paling penting untuk dimiliki oleh distributor bagi konsumen, yaitu: price, product, process, promotion, dan physical evidence.

Tabel 10. The CPM PT. X, Pesaing A, dan Pesaing B

\begin{tabular}{|l|c|c|c|c|c|c|c|}
\hline \multirow{2}{*}{ Critical Success Factors } & \multirow{2}{*}{ Weight } & \multicolumn{2}{|c|}{ PT. X } & \multicolumn{2}{c|}{ Pesaing A } & \multicolumn{2}{c|}{ Pesaing B } \\
\cline { 3 - 8 } & & Rating & Score & Rating & Score & Rating & Score \\
\hline Price & 0.22 & 3 & 0.67 & 3 & 0.67 & 3 & 0.67 \\
\hline Product & 0.21 & 3 & 0.63 & 3 & 0.63 & 3 & 0.63 \\
\hline Process & 0.17 & 3 & 0.50 & 2 & 0.33 & 3 & 0.50 \\
\hline Promotion & 0.13 & 3 & 0.38 & 3 & 0.38 & 3 & 0.38 \\
\hline Physical Evidence & 0.11 & 3 & 0.33 & 2 & 0.22 & 3 & 0.33 \\
\hline People & 0.09 & 3 & 0.27 & 2 & 0.18 & 3 & 0.27 \\
\hline Place & 0.07 & 3 & 0.22 & 2 & 0.15 & 2 & 0.15 \\
\hline \multicolumn{1}{|c|}{ Total } & $\mathbf{1 . 0 0}$ & & $\mathbf{3 . 0 0}$ & & $\mathbf{2 . 5 6}$ & & $\mathbf{2 . 9 3}$ \\
\hline
\end{tabular}


Pada Tabel 10 didapatkan bahwa PT. X memiliki nilai yang lebih besar dibanding Pesaing A dan Pesaing B. Meskipun demikian, nilai PT. X dan Pesaing $B$ hanya terpaut sedikit dan hanya berbeda pada bagian place. Pesaing A merupakan distributor yang berada di wilayah Bandung sedangkan Pesaing B merupakan distributor yang berada di luar wilayah Bandung. Agar PT. X tidak terkejar oleh Pesaing B, maka PT. X perlu mempertahankan dan meningkatkan performansinya saat ini.

Karena nilai price dan product tergantung dari pihak produsen, maka untuk dapat bertahan dalam persaingan, PT. $X$ dapat memberikan nilai tambah pada faktor lain. Berikut ini alternatif strategi yang dapat dilakukan oleh PT. X, yaitu:

1) Membuat sistem pemesanan online.

2) Menambahkan pengaman pada saat melakukan pengiriman produk rak piring.

3) Menanggapi keluhan konsumen dengan sikap yang baik.

4) Melakukan promosi melalui media sosial.

5) Melakukan manajemen persediaan yang menggunakan sistem teknologi informasi.

6) Menerapkan sistem punishment bagi supir dan kenek yang tidak menutup produk dengan terpal pada saat pengiriman.
7) Mengadakan pelatihan yang meningkatkan product knowledge serta interpersonal skill karyawan PT. X, khususnya bagi karyawan yang berinteraksi langsung dengan konsumen.

8) Membuat website perusahaan.

\section{The Strengths-Weaknesses-Opportunities- Threats (SWOT) Matrix}

Penentuan faktor-faktor yang ada dalam The SWOT Matrix (lihat Tabel 11) didasarkan dari analisis lingkungan internal (analisis strategi pemasaran PT. X saat ini, analisis internal perusahaan) yang menghasilkan faktor strengths dan weaknesses, serta didasarkan dari analisis lingkungan eksternal (PESTLE analysis, analisis Porter's Five Forces Model) yang menghasilkan faktor opportunities dan threats.

Berdasarkan hasil kuesioner dalam analisis marketing mix PT. X, diketahui bahwa nilai PT. X dalam setiap pernyataan lebih baik atau hampir sama baiknya dengan nilai yang didapatkan oleh Pesaing A atau Pesaing B. Oleh karena itu, hanya pernyataan yang mendapatkan nilai lebih dari 3 yang dimasukkan sebagai strengths PT. X dan pernyataan yang nilainya kurang dari 3 dimasukkan sebagai weaknesses PT. X. 
Tabel 11. The SWOT Matrix PT. X

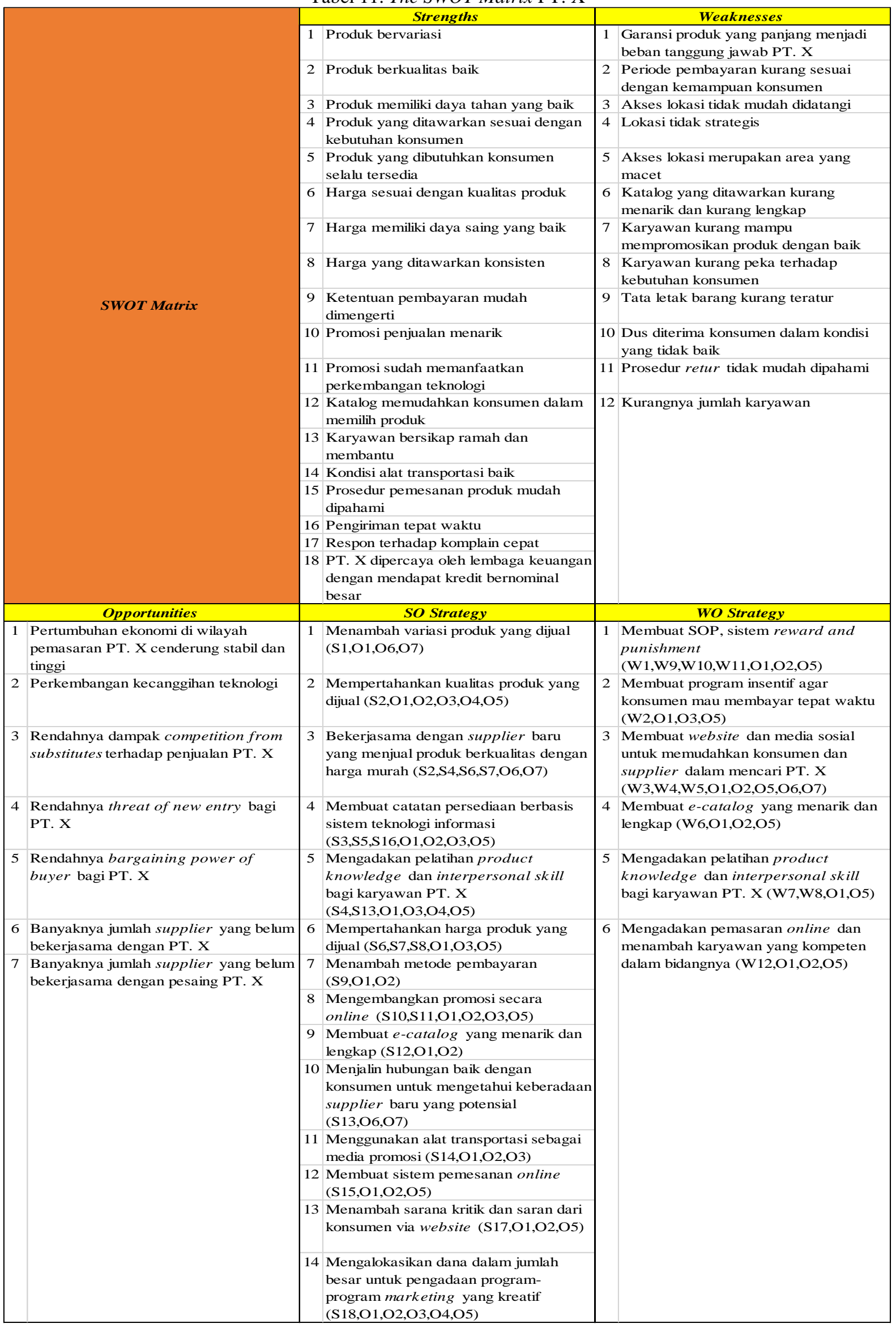


Tabel 11. The SWOT Matrix PT. X Lanjutan

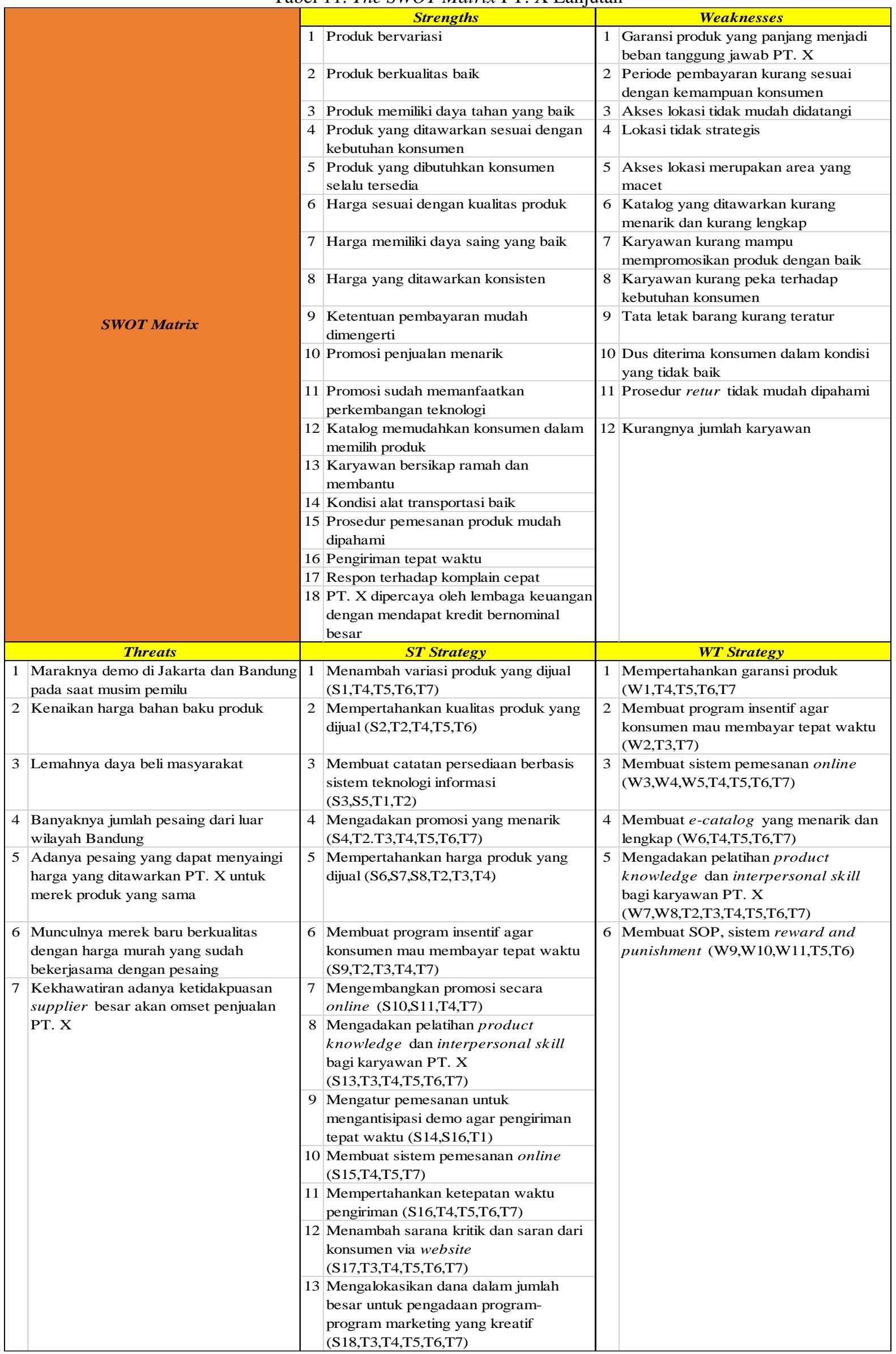




\section{Usulan Prioritas Strategi untuk PT. X}

Berikut ini alternatif strategi yang dipilih sebagai usulan prioritas strategi bagi PT. X berdasarkan hasil wawancara terhadap Direktur PT. X dan hasil observasi di PT. X.

1) Mengadakan pelatihan product knowledge dan interpersonal skill bagi karyawan PT. X.

2) Membuat catatan persediaan berbasis sistem teknologi informasi.

3) Memanfaatkan teknologi dalam kegiatan pemasaran (membuat $e$-catalog yang menarik dan lengkap, membuat sistem pemesanan online, mengembangkan promosi secara online).

4) Membuat SOP (pemesanan, pengiriman, pembayaran, retur) serta sistem reward and punishment untuk karyawan PT. X.

\section{KESIMPULAN DAN SARAN}

\section{Kesimpulan}

Ada beberapa kesimpulan yang didapatkan dari penelitian ini, antara lain:

1. Strategi pemasaran PT. X saat ini dilihat dari penetapan segmenting, targeting, dan positioning serta penerapan marketing mix yang dilakukan oleh perusahaan. PT. X menetapkan business market segmenting yang mempertimbangkan type of organization, organizational characteristics, benefits sought or buying process, personal and physhological characteristics, dan relationship intensity. Untuk penetapan targeting, PT. X menggunakan market specialization. Berdasarkan hasil crosstab diketahui bahwa sebaiknya PT. X fokus kepada konsumen yang telah mendirikan toko selama $6-20$ tahun, telah bekerjasama selama $1-15$ tahun dengan PT. X, serta konsumen-konsumen yang memilih PT. X sebagai prioritas pertama untuk diajak bekerjasama, khususnya konsumen yang memiliki omset toko per bulan sebesar Rp 40.000.000 - Rp 59.999.999. Dalam segi positioning, PT. X menetapkan citra sebagai distributor yang menjual produk berkualitas dengan harga murah. Penerapan marketing mix PT. X dilihat dari 7 aspek, yaitu:

a. Product

PT. X menjual produk furniture yang terbuat dari plastik (lemari pakaian), aluminium (rak piring, jemuran), dan besi (tangga). Saat ini ada 11 merek furniture yang dijual PT. X (Club, Master, Naiba, Matsuo, Akako, USA, Galaxy, Bina Karya, Arion, Nasional, dan Mascot), dimana PT. X memperhatikan kualitas, harga, dan merek saat bekerjasama dengan produsen. Jumlah produk yang dipesan oleh konsumen harus sesuai dengan kelipatan jumlah produk yang ada dalam dus. Apabila ada produk yang rusak, PT. X menyediakan retur selama produsen masih memproduksi produk tersebut. PT. X mengadakan persediaan di gudang agar produk yang dijual tersedia saat konsumen memesan.

b. Price

PT. X menentukan harga jual dengan memperhitungkan Harga Pokok Penjualan (HPP), biaya operasional perusahaan (biaya gaji, biaya pengiriman), dan jumlah keuntungan yang diinginkan perusahaan. Harga yang ditetapkan sesuai untuk kalangan menengah kebawah. Periode pembayaran yang diterapkan oleh PT. X adalah 30 - 45 hari, dimana konsumen dapat membayar secara tunai, Bilyet Giro (BG), atau transfer ke rekening PT. X. Untuk pembayaran secara tunai, PT. X memberikan potongan $3 \%$ dari total pemesanan.

c. Place

PT. X memiliki lahan seluas $1.400 \mathrm{~m}^{2}$, dimana luas bangunan gudangnya adalah $350 \mathrm{~m}^{2}$. Dengan luas tersebut, PT. X memiliki kapasitas gudang yang dapat menampung $8.000-9.000$ produk per bulan . Lokasi PT. X berada di daerah Kabupaten Bandung dan terletak di pinggir jalan raya.

\section{d. Promotion}

Saat ini PT. X melakukan promosi dengan cara: menggunakan katalog dari produsen, by phone untuk menanyakan apakah konsumen mau melakukan pemesanan serta 
menginformasikan produk baru yang belum ada dalam katalog, pemberian baju ke konsumen dengan melihat history pemesanan konsumen serta lamanya kerjasama konsumen dengan PT. X, pemberian sistem paket jika produsen melakukan promosi serupa.

e. People

Secara umum pegawai yang dicari PT. X adalah pegawai yang jujur dan rajin. Untuk supir, PT. X mencari orang yang memiliki SIM A dan dapat mengendarai truk atau mobil pick-up dengan baik. Untuk staf penjualan harus memiliki SIM C dan kendaraan bermotor. Untuk staf kantor, PT. $\mathrm{X}$ mencari orang yang mampu menggunakan aplikasi Microsoft Word dan Microsoft Excel. PT. X menarik semangat staf penjualan dengan pemberian komisi. Apabila ada staf penjualan yang merencanakan resign, staf tersebut harus mendapatkan pengganti dan memperkenalkan staf baru kepada konsumen yang menjadi tanggung jawab staf tersebut.

f. Physical evidence

Physical evidence PT. X terlihat dari: kondisi tata letak barang (Kepala Gudang PT. X memastikan produk tidak ditumpuk secara berlebihan dan menempatkan produk yang paling sering dipesan konsumen di dekat area pintu gudang), kondisi alat transportasi (PT. X memiliki 14 kendaraan dimana 2 kendaraan berada dalam kondisi yang kurang baik), dan kondisi dus dari produk yang dijual (berdebu atau rusak karena kena air hujan).

g. Process

Process yang dibahas ada 3 , yaitu: proses pemesanan produk (konsumen dapat memesan langsung ke staf penjualan secara face to face atau by phone, serta dapat menelpon langsung ke kantor, dimana konsumen paling lama menunggu $2-5$ hari jika pesanan tidak tersedia di gudang), proses pengiriman produk (PT. X memastikan bahwa terdapat bukti berupa tandatangan dan cap konsumen pada surat jalan yang sudah disetujui oleh Kepala Administrasi Umum, Pengawasan dan Pergudangan PT. X), dan proses penanganan keluhan konsumen (keluhan yang pernah diterima oleh PT. X terkait kondisi produk yang rusak, warna produk yang berbeda dengan pesanan, dan lamanya waktu pengiriman produk).

2. Berikut ini analisis lingkungan internal dan eksternal dari PT. X:

a. Analisis Lingkungan Internal

Penetapan segmenting, targeting, dan positioning PT. X sudah sesuai dengan keinginan Pemilik PT. X, dan penerapan marketing mix PT. X dinilai baik oleh konsumen. Dalam aspek internal perusahaan, PT. X memiliki competitive advantage dalam hal low cost.

b. Analisis Lingkungan Eksternal Berdasarkan hasil PESTLE Analysis diketahui bahwa legal factor dan environment factor tidak berpengaruh secara signifikan terhadap PT. X. Faktor yang berpengaruh secara signifikan ada 4 , yaitu: political factor, economic, social factor, dan technological factor. Hasil Porter's Five Forces Model menunjukkan bahwa threats of new entry, bargaining power of buyers, dan competition from substitutes memberikan pengaruh yang rendah terhadap PT. X, sedangkan rivalry between established competitors dan bargaining power of suppliers memberikan pengaruh yang sedang terhadap PT. X.

3. Rekomendasi strategi pemasaran bagi PT. X didapatkan dari hasil analisis terhadap alternatif strategi yang didapatkan dari The CPM dan The SWOT Matrix. Ada 4 rekomendasi strategi pemasaran yang diusulkan, yaitu:

1) Mengadakan pelatihan product knowledge dan interpersonal skill bagi karyawan PT. $\mathrm{X}$.

2) Membuat catatan persediaan berbasis sistem teknologi informasi. 
3) Memanfaatkan teknologi dalam kegiatan pemasaran (membuat e-catalog yang menarik dan lengkap, membuat sistem pemesanan online, mengembangkan promosi secara online).

4) Membuat SOP (pemesanan, pengiriman, pembayaran, retur) serta sistem reward and punishment untuk karyawan PT. X.

\section{Saran}

1. PT. X dapat mengadakan pelatihan knowledge terkait pengetahuan tentang produk sehingga karyawan dapat mempromosikan produk dengan baik. Pelatihan interpersonal skill terkait bagaimana cara membangun hubungan yang baik dengan konsumen diperlukan oleh PT. X agar karyawan PT. $X$ dapat membuat konsumen merasa dekat dengan perusahaan, konsumen menjadi loyal, dan perusahaan mendapat informasi penting (seperti: keberadaan supplier baru atau merek produk yang beredar di pasaran serta kualitasnya, kebutuhan serta keinginan konsumen).

2. PT. X dapat membuat catatan persediaan yang berbasis sistem teknologi informasi untuk menentukan jumlah dan produk apa saja yang harus disimpan dalam gudang.

3. PT. X dapat memanfaatkan teknologi dalam kegiatan pemasaran dengan cara menggunakan media sosial (Facebook, Instagram, WhatsApp) sebagai sarana e-catalog (dengan tidak meniadakan katalog yang ada saat ini) untuk memudahkan konsumen melihat produk yang dijual PT. X, terutama produk baru yang belum ada dalam katalog saat ini. E-catalog tersebut dibuat menarik (gambar setiap produk diatur sedemikian rupa agar tampilan menjadi eye catching) dan lengkap (berisi semua produk yang dijual PT. X serta spesifikasi setiap produk, terutama untuk produk baru). Selain itu, PT. $X$ dapat mengadakan pemesanan online dengan membuat aplikasi sederhana pada smartphone, dimana pada aplikasi tersebut konsumen dapat melakukan pemesanan dengan mudah. PT. X juga dapat melakukan promosi online menggunakan media sosial (mengirimkan pesan broadcast via WhatsApp kepada konsumen atau postingan di Facebook dan Instagram tentang promo yang ditawarkan oleh PT. X).

4. Agar setiap proses dalam PT. X dapat berjalan dengan teratur, maka PT. X sebaiknya membuat Standard Operating Procedure (SOP). Untuk memastikan bahwa SOP tersebut berjalan dengan baik, maka PT. X dapat menerapkan sistem reward and punishment kepada karyawannya. Pemberian reward dapat berupa pemberian bonus bagi staf penjualan yang memenangkan kompetisi dalam pencapaian omset penjualan terbanyak. Pemberian punishment dapat berupa teguran atau sanksi (misalnya: teguran tertulis, supir dan kenek mengganti biaya pembelian dus).

\section{DAFTAR PUSTAKA}

Andersen, Torben. J. (2013). Short Introduction to Strategic Management, $1^{\text {st }}$ ed. Cambridge University Press, United Kingdom.

BPS. (2014). Tinjauan Regional Berdasarkan PDRB Kabupaten/Kota 2010-2013: Pulau Jawa dan Bali. Badan Pusat Statistik, Jakarta.

BPS. (2015). Tinjauan Regional Berdasarkan PDRB Kabupaten/Kota 2010-2014: Pulau Jawa dan Bali. Badan Pusat Statistik, Jakarta.

BPS. (2016). Tinjauan Regional Berdasarkan PDRB Kabupaten/Kota 2011-2015: Pulau Jawa dan Bali. Badan Pusat Statistik, Jakarta.

BPS. (2017). Tinjauan Regional Berdasarkan PDRB Kabupaten/Kota 2012-2016: Pulau Jawa dan Bali. Badan Pusat Statistik, Jakarta.

BPS. (2018). Tinjauan Regional Berdasarkan PDRB Kabupaten/Kota 2013-2017: Pulau Jawa dan Bali. Badan Pusat Statistik, Jakarta.

BPS. (2019). Tinjauan Regional Berdasarkan PDRB Kabupaten/Kota 2014-2018: Pulau Jawa dan Bali. Badan Pusat Statistik, Jakarta.

BPS. (2020). Tinjauan Regional Berdasarkan PDRB Kabupaten/Kota 2015-2019: Pulau Jawa dan Bali. Badan Pusat Statistik, Jakarta.

BPS. (9 Tinjauan Regional Berdasarkan PDRB Kabupaten/Kota 2010-2014: Pulau Jawa dan Bali. Badan Pusat Statistik, Jakarta. 
BPS. (2020). KBLI: Klasifikasi Baku Lapangan Usaha Indonesia 2020. Badan Pusat Statistik, Jakarta.

BPS. (2017). Statistik Indonesia: Statistical Yearbook of Indonesia 2016. Badan Pusat Statistik, Jakarta.

BPS. (2019). Statistik Indonesia: Statistical Yearbook of Indonesia 2019. Badan Pusat Statistik, Jakarta.

BPS. (2021). Statistik Indonesia: Statistical Yearbook of Indonesia 2021. Badan Pusat Statistik, Jakarta.

David, Fred R. dan David, Forest R. (2015). Strategic Management: Concept and Cases, $15^{\text {th }}$ ed. Global ed. Pearson Education, London.

Grant, Robert M. (2010). Contemporary Strategy Analysis, $7^{\text {th }}$ ed. John Willey \& Sons Ltd, United Kingdom.

Ferrel, O. C. dan Hartline, Michael D. (2014). Marketing Strategy: Text and Cases, $6^{\text {th }}$ ed. South-Western, USA.

Irawati, Rika H. dan Purnomo, Herry. (2012). Pelangi di Tanah Kartini: Kisah Aktor Mebel Jepara Bertahan dan Melangkah ke Depan. CIFOR, Bogor.

Kompas. (2020, Agustus 11). Pandemi Covid-19, Apa Saja Dampak pada Sektor Ketenagakerjaan Indonesia? Jakarta, Indonesia.

https://apple.co/3hXWJ0Lhttps://www.ko mpas.com/tren/read/2020/08/11/10250016 5/pandemi-covid-19-apa-saja-dampakpada-sektor-ketenagakerjaan-indonesia?page $=$ all

Kotler, Philip dan Keller, Kevin L. (2012). Marketing Management, $14^{\text {th }}$ ed. Prentice Hall, New Jersey.

Kotler, Philip dkk. (2016). The Quintessence of Strategic Management: What You Really Need to Know to Survive in Business, $2^{\text {nd }}$ ed. Springer, London.

Oxford. (2014). Little Oxford English Dictionay. Oxford University Press, Oxford.

Rao, P. S. (2010). Strategic Management: Including Skill Development. Himalaya Publishing House, Mumbai.

Sekaran, Uma. (2010). Research Methods for Business: A Skill Building Approach, $5^{\text {th }}$ ed. John Wiley \& Sons Ltd, United Kingdom.

Silalahi, Ulber. (2009). Metode Penelitian Sosial. Refika Aditama, Bandung.

Tjiptono, Fandy. (2015). Strategi Pemasaran, $4^{\text {th }}$ ed. Penerbit Andi, Yogyakarta.
Wilkinson, Timothy J. dan Kannan, Vijay R. (2013). Strategic Management in the $21^{s t}$ Century: The Operational Environment, $1^{\text {st }}$ ed. ABC-CLIO LLC, California.

Zimmerman, Alan dan Blythe, Jim. (2013). Business to Business Marketing Management: A Global Perspective, $2^{\text {nd }}$ ed. Routledge, London dan New York. 